\title{
WILL BREXIT HARM UK AND GLOBAL WINE MARKETS?
}

\author{
BRIEFING PAPER 9 - MAY 2017 \\ KYM ANDERSON AND GLYN WITTWER \\ UK TRADE POLICY OBSERVATORY
}

\section{KEY POINTS}

- For wine markets, the impact of the UK leaving the Customs Union is likely to come not only from tariff changes but also from slowed growth of UK incomes and devaluation of the pound.

- $\quad$ Even if the UK were to sign new trade agreements with the EU27 and others, the time it would take to implement them and for markets to adjust ensures that the likely effects of Brexit on wine markets will be adverse over the next few years.

- In the main scenario considered, for consumers in the UK the price of wine in 2025 is $22 \%$ higher in local currency terms than it would be without Brexit, the volume of UK wine consumption is $28 \%$ lower, and the value of UK imports is $27 \%$ lower because of Brexit.

- Such a sales reduction in the UK would be a blow to participants in UK wine bottling, transporting, storing, wholesaling and retailing businesses, as well as restaurants and pubs.

- Because the UK is a key player in global wine trade, accounting for a major share of the world's wine imports, Brexit will also affect wine-exporting countries, with few if any gaining in the main scenario considered over the modelled projection period to 2025.

\section{INTRODUCTION}

The UK has accounted for a major share of the world's wine imports for centuries, and wine currently accounts for more than one-third of UK alcohol consumption. Its withdrawal from the European Union (Brexit) therefore will affect not only UK wine consumers, producers, traders, distributors and retailers but also suppliers of those imports. A model of the world's wine markets is used to indicate both domestic and foreign impacts of various alternative Brexit scenarios, which involve adjustments to UK and EU27 bilateral tariffs on wine imports and any changes to UK income growth and the value of the pound over the period of adjustment. The relative importance of each of those three components in three alternative Brexit shocks are reported, as are the impacts on bilateral wine trade values and volumes. The results suggest the percentage impacts outside the
UK will be minor compared with other developments in the world's wine markets. Inside the UK, however, the effects of Brexit on incomes and the pound may well have a much more significant impact on the domestic wine market than changes in bilateral wine tariffs.

\section{WILL BREXIT HARM UK AND GLOBAL WINE MARKETS?}

The UK's planned withdrawal from the European Union (Brexit) will affect markets for many products, including wine. True, very little wine is produced in the UK (although the volume is now five times what it was in the 1980s), and wine accounts for just $0.5 \%$ of UK merchandise imports. Over the past six decades, though, wine's share of UK alcohol consumption has steadily risen from a mere $5 \%$ to more than oneOBSERVATORY

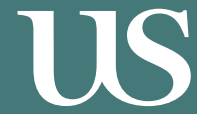

UNIVERSITY OF SUSSEX
CHATHAM HOUSE

The Royal Institute of International Affairs 
third. Wine traders, distributors and retailers - in addition to consumers - are therefore concerned about Brexit's potential impact on them. Brexit is attracting considerable attention to wine producers and consumers outside the UK too, because the UK has always accounted for a major share of the world's wine imports.

To examine how wine markets might be affected by Brexit, one needs to look beyond the immediate tradereducing and trade-diverting effects of altering bilateral import tariffs. The process of exiting - establishing new trading arrangements and adjusting to the altered incentives - is expected to take several years and, in the interim, to possibly slow the growth of UK incomes and devalue the pound. We therefore begin with a projection of how wine markets will look in several years' time had the Brexit vote gone the other way, and then show how that projection of the world's wine markets would change under three alternative Brexit scenarios. After reviewing the UK's role in global wine markets, we provide such an analysis using a model of the world's wine markets projected to 2025 .

\section{WINE IN THE UK, AND THE UK IN GLOBAL WINE MARKETS}

Wine has averaged just $0.5 \%$ of UK merchandise imports since World War I, and prior to 1950 it accounted for no more than $4 \%$ of the volume of alcohol consumed in the UK (although somewhat more as a share of alcohol expenditure). Over the past six decades, however, wine's share of UK alcohol consumption has steadily risen, and it now exceeds one-third in both volume and value terms (Figure 1).

The UK is a very important player in wine trade circles, as it has always accounted for a major share of the world's wine imports. The UK's share of the value of world imports of wine was above $20 \%$ in the 19th century. It steadily declined to around $10 \%$ by 1960 , but then climbed back above $20 \%$ by the beginning of the present century.

The UK's importance to producers in wine-exporting countries is clear from Figure 2. For seven key suppliers, the UK accounted for more than one-sixth of their wine export earnings during 2010-14. For three of them (Australia, the US and New Zealand), the UK is a market for more than one-third of their volume of wine exports. Such exporters might expect to gain from Brexit by being able to export to the UK on the same terms as EU27 exporters (and also Chilean and South African exporters who have had preferential access to all EU28 markets). But it needs to be kept in mind that the average wine tariff on non-EU imports into the UK currently is only about 13 pence per litre, which is minor compared with the UK's weighted average wine excise duty of almost $£ 3$ per litre and the $20 \%$ VAT.

\section{FIGURE 1: WINE'S SHARES OF UK MERCHANDISE IMPORT VALUE SINCE 1800 AND OF VOLUME AND VALUE OF UK ALCOHOL CONSUMPTION, ${ }^{\text {a }} 1950$ TO 2015 (\%)}

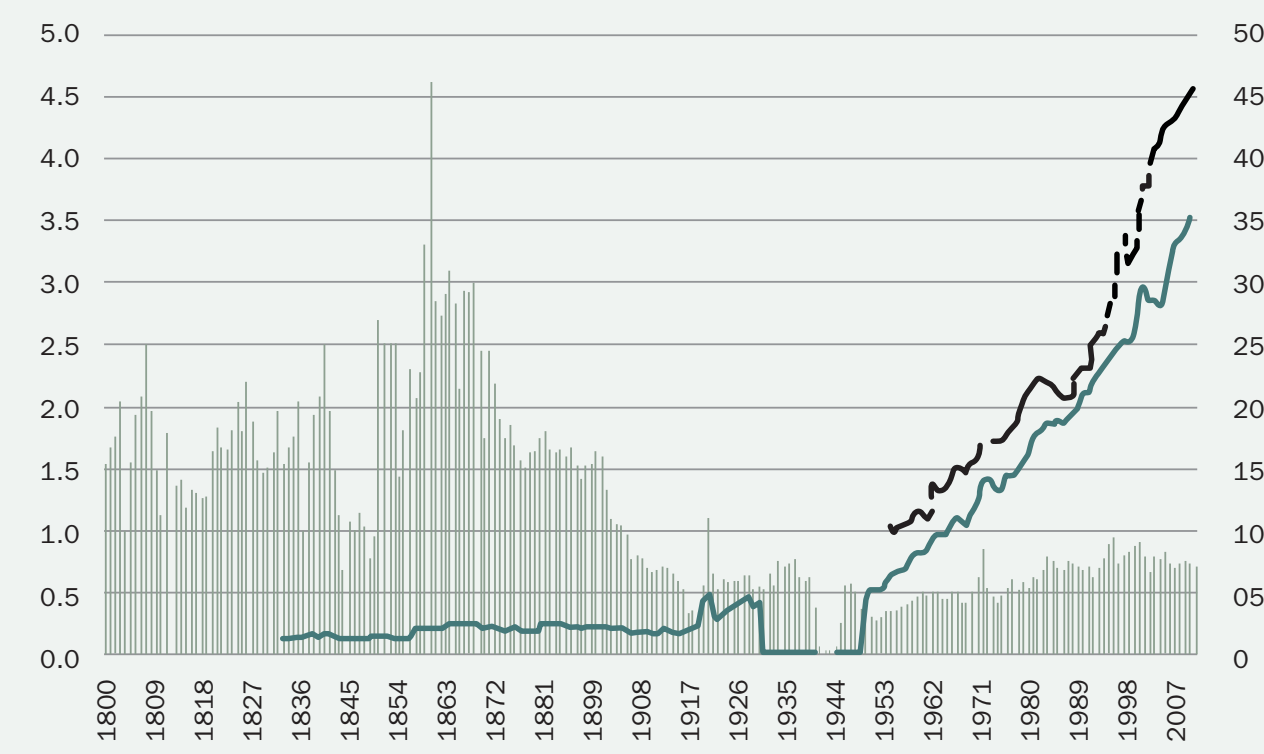

45

40

30

25

10

05

a Reliable wine consumption volume data are not available for the 1930s and 1940s, nor are value of alcohol consumption data pre-1955. Source: Anderson and Pinilla (2017). 
FIGURE 2: SHARES OF UK IN WINE EXPORTS OF KEY WINE-EXPORTING COUNTRIES, 2010-14 (\%)

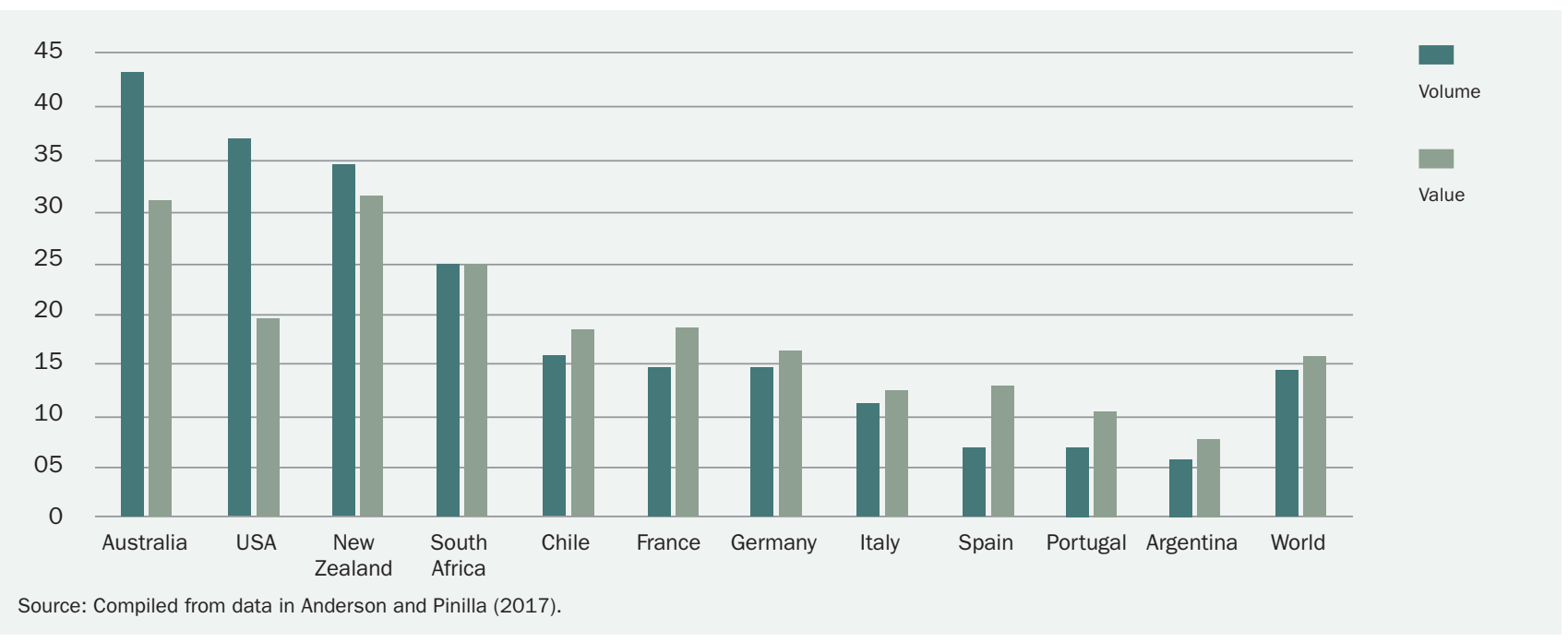

\section{THE ECONOMICS OF LEAVING A CUSTOMS UNION}

When countries join a customs union - which abolishes tariffs on trade between them and imposes a common external tariff on imports from non-union countries - there may or may not be net external trade creation (depending on the height of the common external tariff relative to the previous national tariffs), but there will also be trade diversion (because the preference to producers within the union means some imports from the rest of the world are displaced by imports from other union countries). When a country leaves a customs union, the reverse happens: the leaving country's tariffs will now apply to its imports from union countries as well as from the rest of the world. Hence imports from the union will fall, because their preferential access to the leaving country will no longer apply. That is also the case for countries that enjoyed a free trade agreement (FTA) with the union, which is of significance to wine because Chile currently has tariff-free access to the UK through its FTA with the EU, as does South Africa for a certain volume of its wine imports.

The extent of the reversal of external trade creation and trade diversion on wine depends on the external tariff imposed on wine imports not only by the union but also by the leaving country. Some have suggested the UK should become the Hong Kong of Europe and go immediately to free trade on all products. We consider this below and call it our free trade scenario. Others have suggested that this is politically unlikely as it would impose huge structural changes on the UK economy which society would not tolerate without major compensation packages. In either case, a new trade policy which sets most-favoured-nation tariff rates is needed before the UK can begin to negotiate new preferential trading arrangements with the EU27, its FTA partners such as Chile and South Africa, or other countries. Rollo et al. (2016) suggest the most practical trade policy for the UK to adopt at the outset is the EU's tariff schedules previously agreed to at the World Trade Organization (WTO). In the other two Brexit scenarios examined below, we assume this will be the new UK trade policy, that subsequent negotiations for preferential arrangements will take years and that the implementation of any consequent agreements with the EU or others will not be felt before 2025 .

The impact of leaving a customs union on wine markets comes not only from tariff changes. Also relevant are any effects that leaving has on real UK expenditure of incomes and the value of the pound. If the UK were to move to free trade on all products, its per capita income could eventually rise, but only after considerable adjustment which we assume would not be complete before 2025. Should the UK instead adopt the EU tariff schedule in the first instance and lock that in at the WTO, as we assume in the other two scenarios below, then its per capita income growth rate will almost certainly drop and we assume the recent fall in the value of the pound against other currencies will not recover before 2025. We cannot be certain as to the extent of those impacts, of course, so we consider below both a 'large' and a 'small' adverse macroeconomic scenario. Both will add to the impact of the tariff changes on aggregate wine consumption in the UK and hence on its bilateral trades in wine, making the loss of sales to the UK by EU (and Chilean and South African) suppliers greater than they would be otherwise. Furthermore, they reduce the likelihood that other countries' sales of wine in the UK will be higher than the baseline. Indeed, the 
macro effects could outweigh the trade-diverting effects, so that even countries that are currently discriminated against by the EU28's wine trade policy may be worse off because of Brexit.

\section{MODELLING GLOBAL WINE MARKETS TO 2025}

The authors' model of the world's wine markets (Anderson and Wittwer 2013) disaggregates wine markets into non-premium, commercial-premium and super-premium still wines, and sparkling wine. It also divides the world into 44 individual nations and 7 composite geographic regions that capture all other countries. The model's database is calibrated to 2014 and projected forward to 2025 assuming aggregate national consumption, population, and real exchange rates change to the extent shown in Anderson and Wittwer (2017, Appendix Table 1). Each of the four types of wines of each country are imperfect substitutes for wines from all other countries.

The three Brexit alternatives to the 2025 baseline that we consider below ('free trade', 'large' and 'small') assume that the rate of UK economic growth is unchanged or is reduced to either $0.9 \%$ or $1.8 \%$ instead of $2.6 \%$ per year, and that the UK pound in 2025 will either be unchanged from 2014's rate or be $20 \%$ or $10 \%$ lower in real terms. We also assume in the 'large' and 'small' scenarios that the UK will apply the EU's external tariffs on wine to imports from EU member countries, and that the UK will not have enough time by 2025 to negotiate and implement any new free trade agreements (FTAs).

\section{HOW MIGHT WINE MARKETS IN 2025 BE AFFECTED BY BREXIT?}

The 'large' Brexit scenario seems the most likely at this stage, and so we pay most attention to it in this section. The 'free trade' scenario seems the least likely, but we begin with it, and in what follows we also compare results for the 'small' scenario with those for the 'large' scenario.

In our 'free trade' scenario, the UK moves to zero tariffs on all wine imports. Thus the current preferences on EU, Chilean and South African wine imports disappear as all other wine exporters enjoy the same free access to UK wine markets. We assume in this scenario that Brexit has no impact on the UK's real income or consumption growth rates by 2025 and that by then the pound has returned to its 2014 value relative to other currencies. Under these assumptions, EU/Chile/South African wine exports to the UK in 2025 are $0.03 \%$ less than in the no-Brexit baseline, UK imports from other wine exporters are $0.25 \%$ larger, but the UK's total imports of wine are hardly any different. Also, the EU27 exports more and other countries export less to the rest of the world, such that world wine exports are almost unchanged under this Brexit scenario. Within the UK though, consumers enjoy a $0.5 \%$ decline in the local currency price of wine and so expand their volume of consumption by almost $0.5 \%$.

In our 'large' Brexit scenario, as compared with the initial baseline scenario, the consumer price of wine in 2025 would be $22 \%$ higher in the UK in local currency terms (20\% because of real depreciation of the pound, $4 \%$ because of the new tariffs on EU, Chilean and South African wines, and -2\% because of slower UK income growth). The volume of UK wine consumption would be $28 \%$ lower (16\% because of slower UK economic growth, $7 \%$ because of real depreciation of the pound, and $5 \%$ because of the new tariffs). Super-premium still wine sales would be the most affected, dropping by two-fifths, while sparkling and commercial wines would drop by a little less than a quarter. Since the average price rises by more than the fall in the volume sold, the aggregate value of UK sales - even in local currency terms - would fall under this 'large' Brexit scenario. Under the 'small' Brexit scenario (with just half the assumed shocks to incomes and the pound), the consumer price of wine in 2025 would be $11 \%$ higher in the UK and the volume of UK wine consumption would be $17 \%$ lower.

The volume of projected UK imports in 2025 is 432 million litres (ML) or nearly one-quarter lower in the 'large' scenario than in the baseline scenario, comprising $58 \mathrm{ML}$ less sparkling, $32 \mathrm{ML}$ less superpremium still wine, and $342 \mathrm{ML}$ less commercial wine. World imports would be lower by just $240 \mathrm{ML}$ because imports by other countries would be $192 \mathrm{ML}$ higher in response to the international prices of wines being lower in this 'large' scenario. In value terms UK imports are $\$ 1.75$ billion (or 27\%) lower in 2025 because of 'large' Brexit: $\$ 1.12$ billion because of lower incomes, $\$ 0.49$ billion because of the fall in the pound, and $\$ 0.14$ billion because of the rise in wine import tariffs (Table 1). These aggregate trade impacts are just over half as large under the 'small' Brexit scenario.

With levels of imports falling because of raised import tariffs, domestic consumption of all three quality categories of UK-produced wine is lower than without Brexit, as lowered UK incomes and value of the pound are expected to shrink demand for all wines. The pound's devaluation does make it easier for the UK to sell wines abroad though: their exports are 7 ML or nearly 5\% higher in 2025 under Brexit, and UK production is $3 \%$ higher. 
Without Brexit, the UK's shares of global wine imports would have been slightly higher in volume terms in 2025 than in 2010-15, but 2 percentage points lower in value terms thanks to East Asia's expanding demand for imports of premium wines. With 'large' Brexit, however, that value share would be a further 2 percentage points lower, and the volume share would be almost 5 points lower (Figure 3). The net effect of these impacts on global trade are shown in Figure 4: most of the trade effect of Brexit is a large decline in net imports of wine by the UK with very little offsetting positive effect on trade in the rest of the world. The 'small' Brexit numbers are just over half of those in the ‘large' Brexit scenario.

Table 2 reveals that European, Chilean and South African wine exports are significantly lowered by 'large' Brexit (by $151 \mathrm{ML}$ or US $\$ 1.2$ billion in the case of the EU), with some of their exports diverted from the UK to EU27 and other markets in competition with New World exporters. While the US, Australia, Argentina and New Zealand sell only a little less into the UK, they sell less also to other countries because of the increased sales elsewhere by the EU, Chile and South Africa. For Chile and South Africa, who lose their preferential access to UK (but not to EU27) markets in this Brexit scenario, some of their exports are re-directed from the UK to EU27 countries but again they export less overall. Global wine trade in 2025 would be less under Brexit by $240 \mathrm{ML}$ (1.9\%) or $\$ 1.8$ billion (3.5\%).

FIGURE 3: UK SHARES OF WORLD WINE IMPORTS, 2010-15 AND PROJECTED TO 2025 WITHOUT AND WITH BREXIT 'LARGE' SCENARIO (\%)

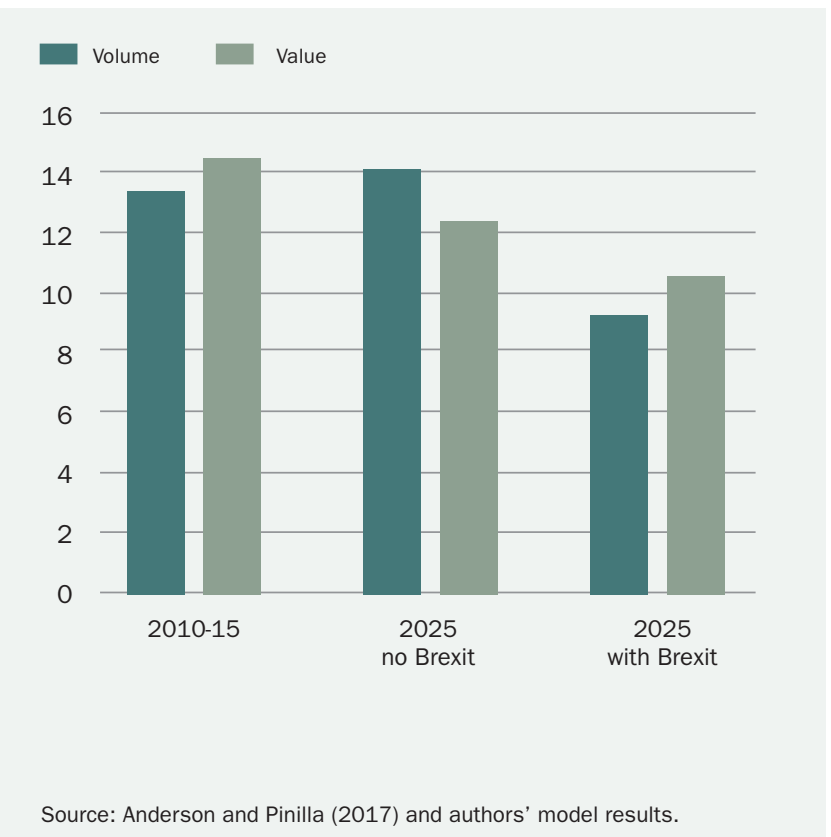

Three other points are worth making from Table 2. One is that Australia sells slightly more to the UK in the 'small' Brexit scenario, but slightly less in the 'large' Brexit case. Evidently, the negative income and devaluation effects in the former scenario do not more than offset the positive trade-diverting effect of removing the EU preference on Australian exports to the UK in the 'small' scenario. Second, New Zealand sells slightly more to non-UK countries under Brexit, despite greater competition from EU27, Chile and South Africa. This anomaly is due to changes in the relative prices of different qualities of wine in global wine markets, bearing in mind that New Zealand has the world's highest average price for still wine exports. And third, the value (but not the volume) of exports of 'Other' countries to markets other than the UK is higher under Brexit. This too is due to changes in the relative prices of different qualities of wine in global wine markets.

The above Brexit simulations are just three of many scenarios that could be explored. Additional scenarios could also assume free trade agreements (FTAs) are reached with the EU27 or other trading partners including Chile and South Africa. Even if the UK were able to sign new FTAs and begin implementing them before 2025, it would make very little difference to the above 'large' or 'small' results (since wine tariffs are a minor contributor to them) unless those FTAs were to reverse our assumed downturn in UK economic growth before 2025 .

\section{FIGURE 4: DIFFERENCE IN 2025 WINE IMPORT VOLUMES AND VALUES AS A RESULT OF BREXIT ‘LARGE' SCENARIO (ML AND US\$ MILLION IN 2014 US DOLLARS)}

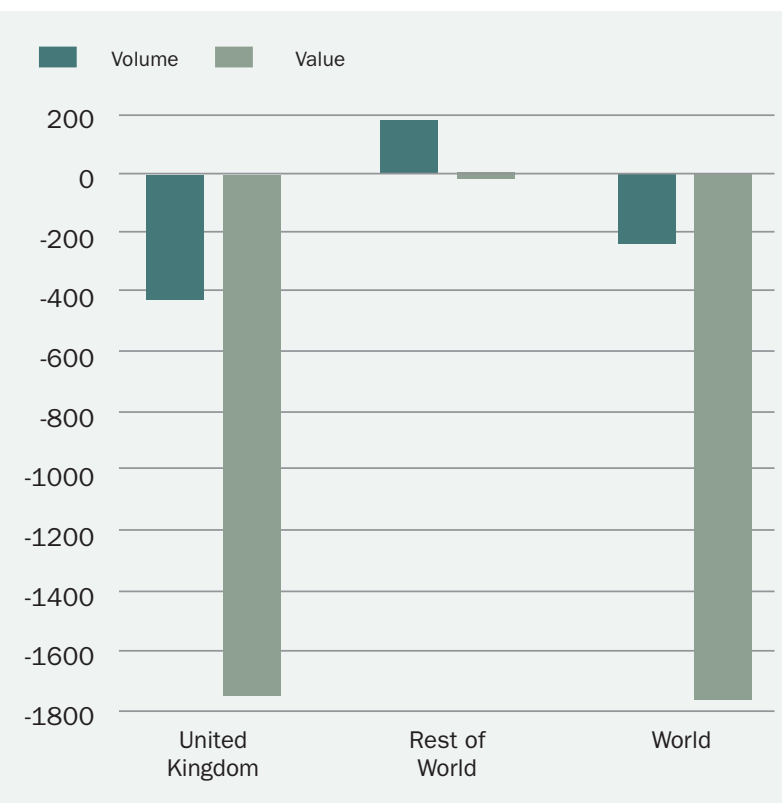

Source: Authors' model results. 


\section{CONCLUSION}

Brexit will be costly to UK consumers of wine (and of many other products) assuming the UK initially adopts the same tariff schedule as the EU. In the 'Iarge' Brexit scenario, the domestic retail price in local currency tax-inclusive terms will be $22 \%$ higher than it otherwise would be in 2025 and the volume of wine consumed domestically will be $28 \%$ lower. Even the 'small' scenario shows $11 \%$ higher prices and $17 \%$ lower quantities. The volume reduction will be a blow to many participants in UK wine bottling, transporting, storing, wholesaling and retailing businesses, in addition to restaurants and pubs. Very little of that impact is because of higher import tariffs; most important are the assumed fall in UK incomes and the pound's devaluation.

The small but growing number of local UK vignerons (who supply less than $0.5 \%$ of all domestic wine sales and less than $4 \%$ of sparkling wine sales) are projected to sell less wine domestically because of reduced demand, and export only a little extra (5\% or $7 \mathrm{ML}$ ) abroad in 2025 with help from the pound's devaluation. Overall their production is just 3\% higher in 2025 in the 'large' Brexit scenario - and this does not take into account the fact that their casual labour is likely to be more expensive under Brexit because of tighter restrictions on immigration.

EU27 wine exporters will export $151 \mathrm{ML}$ or US\$1.2 billion less wine in 2025 thanks to ('large') Brexit, while exporters in the rest of the world will export $90 \mathrm{ML}$ or $\$ 630$ million less in this scenario. The latter group of losing countries includes not only Chile and South Africa - whose preferences into the UK market disappear but also other non-EU wine-exporting countries, notwithstanding the leveling of the playing field in the UK market for imported wine. Wine consumers in countries other than the UK are slightly better off, but only to the extent of an average reduction of $1.6 \%$ in the local currency price of the wines they purchase and an expansion of around $1.0 \%$ in the volume of wine they would consume in 2025 in the 'large' scenario (or about half those magnitudes in the 'small' case). Overall, worldwide wine production and consumption are slightly less under the 'large' and 'small' Brexit scenarios, as we should expect with a rise in protectionism: gains to non-UK consumers are more than outweighed by losses to UK consumers and non-UK producers unless and until new FTAs with major wineexporting countries are implemented.

What could be done to brighten the future of the UK wine market? There are several ways the UK government could help the industry: it could lower taxes on wine consumption (to become more like other EU wine-producing countries); it could adopt lower or zero taxes on wine imports (to become the Hong Kong of Europe); it could join the World Wine Trade Group (to harmonise standards with other wine-exporting countries and lower trade costs); and it could adopt better macroeconomic policies to boost UK economic growth.

\section{REFERENCES}

Anderson, K. and V. Pinilla (with the assistance of A.J. Holmes) (2017), Annual Database of Global Wine Markets, 1835 to 2015, Wine Economics Research Centre, University of Adelaide, to be posted at www.adelaide.edu. au/wine-econ/databases/

Anderson, K. and G. Wittwer (2013), 'Modeling Global Wine Markets to 2018: Exchange Rates, Taste Changes, and China's Import Growth', Journal of Wine Economics 8(2): 131-58.

Anderson, K. and G. Wittwer (2015), 'Asia's Evolving Role in Global Wine Markets', China Economic Review 35: 1-14, September.

Anderson, K. and G. Wittwer (2017), 'The UK and Global Wine Markets by 2025, and Implications of Brexit', mimeo, Wine Economics Research Centre, University of Adelaide, May.
Rollo, J., I. Borchert, K. Dawar, P. Holmes and L.A. Winters (2016), 'The World Trade Organisation: A Safety Net for a Post-Brexit UK Trade Policy?' Briefing Paper 1, UKTPO, University of Sussex, July. http://blogs.sussex.ac.uk/ uktpo/files/2017/01/Briefing-paper-1-final-1.pdf

Swinbank, A. (2017), 'World Trade Rules and the Policy Options for British Agriculture Post-Brexit', Briefing Paper 7 , UKTPO, University of Sussex, January. http://blogs.sussex. ac.uk/uktpo/files/2017/01/Briefing-paper-7.pdf 


\section{APPENDIX}

TABLE 1: DIFFERENCE IN 2025 PROJECTED VOLUME AND VALUE OF WINE IMPORTS BY THE UNITED KINGDOM AND THE REST OF THE WORLD AS A CONSEQUENCE OF BREXIT 'LARGE' SCENARIO (ML AND 2014US\$ MILLION)

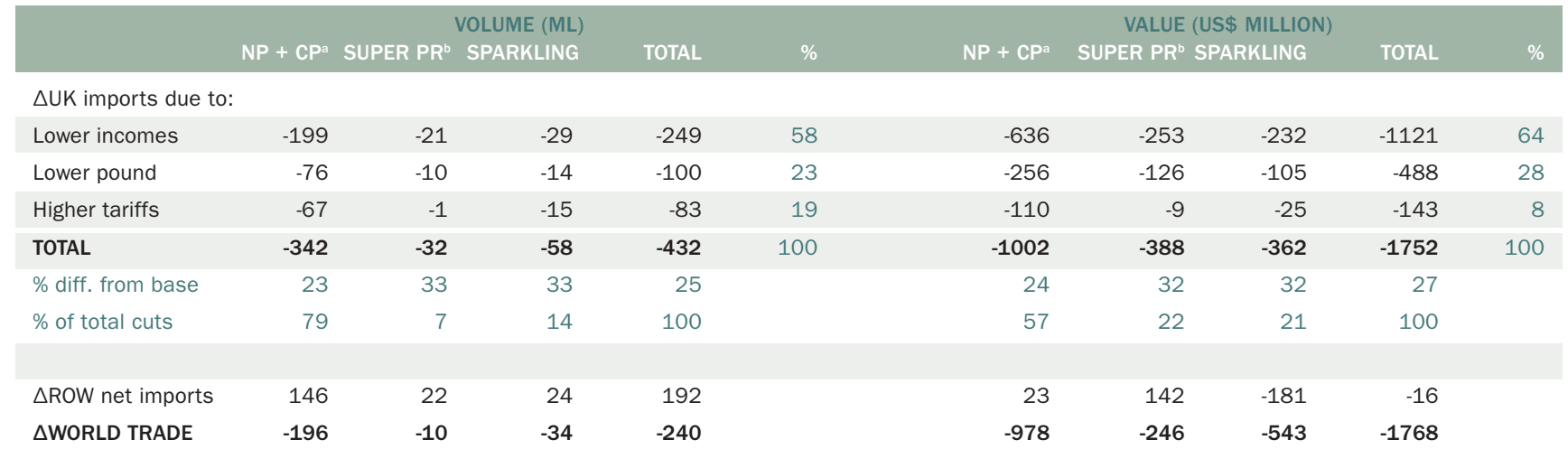

a Non-premium plus Commercial Premium still wines ${ }^{\mathrm{b}}$ Super-premium still wines

Source: Authors' model results.

TABLE 2: DIFFERENCE IN 2025 BILATERAL WINE IMPORT VOLUMES AND VALUES FROM KEY EXPORTERS BY THE UK AND REST OF THE WORLD (ROW) AS A RESULT OF BREXIT (ML AND 2014US\$ MILLION)

(a) 'large' scenario

\begin{tabular}{|c|c|c|c|c|c|c|c|c|}
\hline & \multicolumn{4}{|c|}{ VOLUME (ML) } & \multicolumn{4}{|c|}{ VALUE (US\$ MILLION) } \\
\hline & UK & ROW & WORLD & $(\%)$ & UK & Row & WORLD & $(\%)$ \\
\hline EU27 & -284 & 133 & -151 & $(-1.7)$ & -1182 & -217 & -1399 & $(-3.8)$ \\
\hline Chile & -59 & 35 & -24 & $(-3.0)$ & -170 & 31 & -139 & $(-11.2)$ \\
\hline South Africa & -53 & 35 & -18 & $(-3.2)$ & -106 & 20 & -86 & $(-7.0)$ \\
\hline USA & -7 & -6 & -13 & $(-2.4)$ & -75 & -39 & -114 & $(-4.9)$ \\
\hline Australia & -4 & -3 & -7 & $(-0.9)$ & -25 & -59 & -84 & $(-2.8)$ \\
\hline Argentina & -3 & -9 & -12 & $(-4.8)$ & -16 & -38 & -54 & $(-5.1)$ \\
\hline New Zealand & -11 & 9 & -2 & $(-0.9)$ & -162 & 71 & -91 & $(-4.3)$ \\
\hline Others & -11 & -2 & -13 & $(-0.2)$ & -16 & 215 & 199 & (3.7) \\
\hline WORLD & -432 & 192 & -240 & $(-1.9)$ & -1752 & -16 & -1768 & $(-3.4)$ \\
\hline
\end{tabular}

(b) 'small' scenario

\begin{tabular}{|c|c|c|c|c|c|c|c|c|}
\hline & \multicolumn{4}{|c|}{ VOLUME (ML) } & \multicolumn{4}{|c|}{ VALUE (US\$ MILLION) } \\
\hline & UK & Row & WORLD & $(\%)$ & UK & ROW & WORLD & $(\%)$ \\
\hline EU27 & -178 & 82 & -96 & $(-1.2)$ & -692 & -114 & -806 & $(-2.3)$ \\
\hline Chile & -46 & 28 & -18 & $(-2.4)$ & -128 & 36 & -92 & $(-3.5)$ \\
\hline South Africa & -43 & 29 & -14 & $(-4.2)$ & -83 & 23 & -60 & $(-5.1)$ \\
\hline USA & 1 & -6 & -5 & $(-1.1)$ & -23 & -27 & -50 & $(-2.3)$ \\
\hline Australia & 5 & -10 & -5 & $(-0.6)$ & 19 & -52 & -33 & $(-1.2)$ \\
\hline Argentina & 0 & -6 & -6 & $(-2.6)$ & -3 & -25 & -28 & $(-2.9)$ \\
\hline New Zealand & -5 & 4 & -1 & $(-0.6)$ & -80 & 34 & -46 & $(-2.3)$ \\
\hline Others & 0 & -9 & -9 & $(-0.1)$ & -1 & 93 & 92 & (1.5) \\
\hline WORLD & -266 & 112 & -154 & $(-1.3)$ & -990 & -32 & -1022 & $(-2.0)$ \\
\hline
\end{tabular}

a Numbers in parentheses are the percentage difference between the Brexit and baseline scenarios for 2025 projected wine import volumes or values by source.

Source: Authors' model results. 


\section{ABOUT THE AUTHORS}

Kym Anderson is the George Gollin Professor of Economics and foundation Executive Director of the Wine Economics Research Centre at the University of Adelaide in Australia, where he has been affiliated since 1984. Previously he was a Research Fellow at the Australian National University, following doctoral studies at the University of Chicago and Stanford University; and in 2012 he rejoined ANU part-time as a Professor of Economics in its Crawford School of Public Policy. He was on extended leave at the GATT (now WTO) Secretariat in Geneva during 1990-92 and at the World Bank in Washington DC during 2004-07. He is a cofounder of the American Association of Wine Economists, and a co-editor of its Journal of Wine Economics which is published by Cambridge University Press. CUP will also publish, in late 2017, a multi-authored book he has co-edited on Wine's Evolving Globalization: $A$ New Comparative History. He has also compiled two compendia of global grape and wine data. He is a recipient of an Honorary Doctor of Economics degree from the University of Adelaide and a Distinguished Alumni Award from the University of New England. In 2015 he became a Companion of the Order of Australia $(A C)$.

\section{Kym Anderson}

Wine Economics Research Centre

School of Economics

University of Adelaide

Adelaide, SA 5005 Australia

Email: kym.anderson@adelaide.edu.au

Glyn Wittwer is a Professorial Fellow and Deputy Director of the Centre of Policy Studies at Victoria University in Melbourne, Australia. He specializes in multiregional dynamic modelling of national economies and their resource base, in addition to modelling national and global wine markets. His latest edited volume is Economic Modeling of Water: The Australian CGE Experience (Springer, 2012).

\section{FURTHER INFORMATION}

This document was written by Kym Anderson and Glyn Wittwer for the UK Trade Policy Observatory. It draws on a longer paper by the authors (Anderson and Wittwer 2017). The views expressed are the authors' alone.

The UK Trade Policy observatory (UKTPO), a partnership between the University

of Sussex and Chatham House, is an independent expert group that:

1) initiates, comments on and analyses trade policy proposals for the UK; and

2) trains British policy makers, negotiators and other interested parties through tailored training packages.

The UKTPO is committed to engaging with a wide variety

of stakeholders

to ensure that the UK's international trading

environment is reconstructed in a manner that benefits

all in Britain and is fair to Britain, the EU and the world.

The Observatory offers a wide range of expertise and

services to help support government departments,

international organisations and businesses to

strategise and develop new trade policies in the post-

Brexit era.

For further information on this theme or the work of the UK Trade Observatory, please contact:

Professor L Alan Winters

Director

UK Trade Policy Observatory

University of Sussex, Room 280, Jubilee Building,

Falmer, BN1 9SL

Email: uktpo@sussex.ac.uk

Website: https://blogs.sussex.ac.uk/uktpo/

Twitter: @uk_tpo

ISBN 978-1-912044-65-8

(C) UKTPO, University of Sussex, 2017

Kym Anderson and Glyn Wittwer assert thier moral right to be identified as the authors of this publication. Readers are encouraged to reproduce material from UKTPO for their own publications, as long as they are not being sold commercially. As copyright holder, UKTPO requests due acknowledgement. For online use, we ask readers to link to the original resource on the UKTPO website. 